\title{
Factors Influencing the Total Factor Productivity Growth of Maize Production in Nigeria
}

\author{
*Hassan, Y., Abdullah, A.M., Ismail, M.M. and Mohamed, Z.A. \\ Department of Agribusiness and Information System, Faculty of Agriculture, University Putra Malaysia
}

\begin{abstract}
The study analyzed the maize Total Factor Productivity growth using Data Envelopment Analysis (DEA) based on Malmquist Index in Nigerian. Factors that affect maize total factor productivity growth were also identified using Ordinary Least Square (OLS) method. The study used secondary annual data for the period from 1971- 2010 in order to attain the objective. The result revealed that for the forty-year period of maize production the mean value of TFP was 1.004. This implied a maize total factor productivity growth of $0.4 \%$. In the period of study, the result showed that, the country had registered the total factor productivity growth of $\geq$ 1.00 that stood at $43.6 \%$. While $56.4 \%$ of the time studied the country had a decrease in maize total factor productivity growth, and that confirmed inputs growth rather than an output growth. From 1971-1975 on average the country registered a regress in total factor productivity growth by -3.5\%. However, from 1986-1990 the country had on average registered maize productivity growth of 3.7\%. The result further showed that from 1991-1995 the country had on average experienced a 35.7\% growth in maize productivity in the country. A double digits productivity growth of $33.4 \%$ is also exhibited for the period from 2006-2010.For the determinants of maize total factor productivity growth, research and development spending, net value of production, fertilizer price and labor were identified to have a significant influence on total factor productivity growth .It was recommended that, expanding scope of research and development, net value of production and labor use will help to raise maize productivity growth in the country. Also price of production inputs like fertilizer should be part of government policy priorities.
\end{abstract}

Keywords: Data Envelopment Analysis, Maize, Malmquist Index, Ordinary Least Square Model, Total Factor Productivity Growth

\section{Introduction}

Worldwide production of maize in 2009 stood at 785 million tons, with the largest producer being the United States, producing $42 \%$. Africa produces $6.5 \%$ and the largest African producer is Nigeria with nearly 8 million tons, followed by South Africa [1].In 2010 5,256,430 hectares of maize were planted in Nigeria with a total production of 8,800 million tons [2]. Report shows that, in 20115.150 million hectares were under maize cultivation in Nigeria, with production of 9.250 million tons per annum, giving a yield of 1.8 tons per hectare [3]. This showed even though there was a decrease in the total hectares under maize cultivation in 2011 compared to 2010, the production in 2011 is greater than that of 2010. According to[4] the overall positive productivity effects observed in the sub-regions have implications for national and regional maize policy development in Africa. That sub-regions need to support their member's states to increase productivity rather than acreage cultivated if they are to respond to the challenges being faced by maize growers. Maize is grown in all the ecological zones of the entire country; however, Guinea Savannah zone provides the best ecological condition for maize cultivation. In Nigeria maize is usually intercropped with other crops such as yam, cassava, guinea corn, rice, soybeans, cowpea and groundnut.

Maize is a staple food crop whose consumption is widespread across the country and among households. Maize is prepared as pap, tuwo, gwate, and donkunu, with the cereal cooked, roasted, fried, ground, pounded or crushed form [5]. Maize industrial uses in the brewery and feed industry have been increasing in the previous years: the percentage of total maize production used for feed has increased from 13 to 18 percent of total production [6]. Maize has industrial end uses for both human consumption, example use as flour, beer, malt drinks, cornflakes, starch, syrup and animal consumption, mainly prepared as feed for poultry. Domestic demand of 3.5 million tons outstrips supply of 2.0 million tons per annum. Poultry producers and feed millers are unable to get sufficient corn supplies from local sources and are sought to import. In order to meet the local demand, the government in 2008 had lifted the import ban on corn and allowed at 5\% tariff. Nevertheless, maize price continue to soar to USD400 per ton in 2011/2012 from USD366 per ton as demand continue to increase further [3].

In an attempt to increase maize production extensive research works on maize have been carried out were conducted by National Agricultural Research Institute (NARI) and International Institute for Tropical Agriculture (IITA). Research focus was to develop and introduce improved maize varieties that are disease resistant and high yielding. Consequently maize production has since the mid-1980s increased more than tripled 
not only in West and Central Africa including Nigeria. The development of rapid maturing varieties has enabled maize production to expand into the Sudan Savannah Zone of Nigeria because the zone has short duration of rainy season [7].

Government employed some policy measures to boost maize production in the country. These include the Presidential Transformation Agenda of 2011 aimed to define agriculture as a business, promote private sector investment in agriculture, along with the development of private sector driven marketing organizations, and the promotion of Incentive-based Risk Sharing for Agricultural Lending. The agenda targets maize as a primary value chain to be developed in the North-Central Region and subsequently to other regions in the country. Those government initiatives are activated through a three-tier Government structure. The Federal Government provides general guidance on the policy and macroeconomic framework, while the State and Local Governments are in charge of the implementation. Input procurement and distribution, investment in rural infrastructures, and promotion of marketing institutions are addressed at the State Government Level. The Local Government is to oversee the local provisions of infrastructures.

The Federal Government as well pursue other developmental programs such as the Special Program for Food Security (SPFS) beginning in 2001, the Fadama II Program established in 2003 and the recapitalization of the Nigerian Agricultural, Cooperative and Rural Development Bank (NACRDB) which was launched in 2004. The National Food Security Program (NFSP) includes trade policies, such as import substitution, marketing/price policies, and the promotion of modern agricultural practices. The National Investment Plan (NAIP) was established in 2011-2014. The 5-Point Agenda is coopted in the NAIP and is characterized by five main pillars: (1) Developing Agricultural Policies and Regulatory System (DAPRS); (2) Agricultural Commodity Exchange Market (ACCOMEX); (3) Raising Agricultural Income with Sustainable Environment (RAISE); (4) Maximizing Agricultural Revenue in Key Enterprises (MARKETS); and (5) Water, Aquaculture and Environmental Resource Management. Although maize was excluded from the focus crops of the Presidential Initiative in 2002, it was indeed included among the commodities selected for special focus in the NAIP; those crops include cassava, rice, millet, sorghum, wheat, maize, sugar, cow peas, soya beans, tomato cotton, cocoa, and oil palm. Three initiatives have a general impact on maize, through current public expenditure: Fertilizer policy (procurement and distribution); the National Special Program for Food Security (NSPFS); and the buyer-of-last-resort grain purchase. They represent respectively 43 percent, 22 percent and 26 percent of spending in 2008 [8], with capital expenditure that mainly focused on the purchase of agricultural inputs. However, there are two categories of policies directly impacting maize, namely the price support and input subsidies measures, with view to increasing maize productivity in the country.

Though researches on maize productivity in Nigeria were carried out with a view to enhancing increased maize productivity more need to be researched upon on the productivity of maize particularly in Nigeria where there were a lot of policies, programs and projects geared towards increase in maize productivity in order to achieve food sufficiency in the country and not much were explored on maize productivity growth. The few that researched on the maize productivity growth were mostly on state or regional basis, and have not explored other important areas e.g. maize TFP growth and its components (technological change and efficiency changes) and their determinants. The current study is to evaluate an economic analysis of maize performance in terms of total productivity growth and its determinants in Nigeria.

It is important that for every agricultural development project/program to be developed and encouraged in any society for improving the standard of living of the populace, the priorities of the people in the area should be considered. The rapidly increasing population and demand for maize for human consumption and use as animal feed in the country, requires avenues for raising the productivity of maize per hectare for better standard of living of the populace. This could be achieved through the use of various policies, programs and projects, such as production of maize improved seeds, use of tractors, irrigation scheme etc. geared towards increase in maize productivity growth. This maize productivity growth can be ascertained through this type of current research of analyzing maize productivity growth and as well determine those factors that affect maize productivity growth in the country. $T$ he finding could serve as a guide to government to develop policy measures and introduce development projects in the country.

Previous studies on productivity measures built on the pioneer work of [9] and [10] on efficiency and productivity measurement, respectively. Other analytical techniques for productivity and efficiency measurements include[11] reported on maize total factor productivity growth in Liaoning and Jilin province in China. The author used DEA theoretical framework using Malmquist index calculation. The result showed that corn TFP from 1995 to 2002, average annual growth rate of $0.1 \%$, from 2002 to 2005 , with an average annual growth rate of $1.66 \%$.[12] studied on assessment of the growth of maize production in the Pre-SAP, SAP and Post SAP period in Nigeria. Stochastic frontier analysis was used. The result showed that the compounded rate of growth from 1970-1985(Pre-SAP), 1986-1994(SAP period) and 1995 are $0.001 \%, 0.059 \%$ and $0.025 \%$ respectively. The result showed that SAP period had impact on TFP growth. [13]reported on total factor 
productivity growth in corn production in Iran. Data envelopment analysis (DEA) using Malmquist index was used. Average TFP growth for corn was $-4.5 \%$.

Other studies visited include [14] who reported on productivity growth in food crop production in Imo State, Nigeria using yearly survey for the period from 2001-2007. The authors used decomposition of productivity growth, a stochastic frontier production function approach and in estimating the technical efficiency change; the Translog stochastic frontier model was employed. TFP growth rates decreased from $3.5 \%$ in 2001 to $1.7 \%$ in 2007 . TFP growth was decomposed into technical change, scale effect, technical efficiency and allocative efficiency revealing that the technical change was negative for the period studied.[15] researched on Total Factor Productivity of Manufacturing Sector in India: A Regional Analysis for the State of Haryana. The authors used DEA- Malmquist Index. During 1982-1983 a lowest growth rate of TFP had been observed in comparison to the highest TFP growth of it during the year 1990-1991. During the majority of the years studied, the Malmquist Productivity Index was less than unitary and explaining the level of productivity for manufacturing sector, which is not very encouraging one. It was observed that there was productivity regress in the manufacturing sector of Haryana at the rate of -1.455 per cent per annum. [16] studied on Factor productivity in smallholder pigeon pea production systems: Empirical evidence from Northern Tanzania. The authors used stochastic frontier approach (SFA). Household heads and membership to farmer associations increased from 13.4 to $19.5 \%$ and 18.3 to $24.9 \%$, respectively. Female headed households in the survey increased from $10.6 \%$ in 2008 to $12.2 \%$ in 2010, farmers' access to credit improved from 4.1 to $15.5 \%$. For the determinants of productivity human labor affected the productivity of pigeon pea positively and significantly, plot size has significant and negative coefficient and seed has significant and positive coefficient.[17] studied on determinants of productivity among manufacturing firms in South-Eastern Nigeria: Cobb-Douglas Stochastic Frontier Production Function Approach. Coefficients of Unskilled labour, net productive assets and major raw materials show significant effect on output of the firms. The variables had the expected positive influence at 1 percent probability level. Among the variables specified in the model, registration status, years of operation and size of firms were statistically significant. That showed in Nigeria not much was explored on total factor productivity growth and its determinants using Data Envelopment Analysis and Ordinary Least Squares, respectively.

\section{Methodology}

The study used Data Envelopment Analysis (DEA) based on Malmquist Index to determine total factor productivity growth of maize production in the country. DEA was developed by [18] to provide empirical measure of productive efficiency of decision making units (or DMUs). Efficiency is defined as a ratio of weighted sum of outputs to a weighted sum of inputs, where the weights structure is calculated by means of mathematical programming [18]. Using this approach does not require assuming a particular functional form/shape for the frontier; however they do not provide a general relationship (equation) relating output and input, in addition, there is no need to specify the distributional form for the inefficiency term [19]. DEA convert multiple inputs and outputs in to a single measure of productivity. DEA identifies a "frontier" on which the relative performance of all utilities in the sample can be compared. DEA allocates score of one when compared with another relevant unit, and allocate score of less than one to an inefficient unit. DEA could either be based on output or input orientation. Based output orientation means a frontier is designed in such a way that seeks to maximize output production holding inputs levels constant. While based on input orientation it seeks to use as fewer inputs levels as possible holding output level constant. DEA can be calculated either based on constant return to scale (CRS) or variable return to scale (VRS)assumptions[19] and [20].[21] suggested that the use of VRS decomposes the overall technical efficiency change into pure technical efficiency change and scale efficiency change. In this study it was subscribed based on output orientation and variable return to scale assumption. Using the VRS model, in this research could help to decompose the overall technical efficiency change into pure technical efficiency (PTE) change that relates to the ability of managers to utilize maize farms given resources and scale efficiency (SE) change that refers to exploiting the scale economies by farms operating at a point where the production frontier exhibits constant return to the scale (CRS).

The Malmquist productivity index was introduced as a theoretical index by [22] and popularized as an empirical index by [23].It was introduced as a theoretical index based on the [24] distance function and is widely developed and used in many fields. Malmquist indexes can be used to construct indexes of input, output or productivity, as ratios of input or output distance functions. The most commonly used method for measuring distance functions is linear programming method. Based on the advantages of the Malmquist index over other measures of TFP growth such as the Tornqvist Thiel Index and SFA, in this study I used the Malmquist index to determine the TFP growth based on output distance function (DF). Using this approach does not require price data and does not require the specification or estimation of any function; it is also easy to compute [23]. Distance functions are derived from input-output relationships based on quantity data only. Recently, [25] used this method to estimate agricultural productivity growth for 116 countries. [20]also estimated distance function, 
such as the Malmquist index to measure productivity using data on output and input quantities alone. The Malmquist productivity index is defined on a benchmark technology satisfying constant returns to scale, which is to be distinguished from a best practice technology allowing for variable returns to scale. This convention enables it to incorporate the influence of scale economies, as a departure of the best practice technology from the benchmark technology. Using the period $\mathrm{t}$ benchmark technology, the output oriented Malmquist productivity index is written as:

$M_{o c}^{t}\left(x^{t}, y^{t} x^{t+1}, y^{t+1}\right)=\frac{D_{o c}^{t}\left(x^{t+1}, y^{t+1}\right)}{D_{o c}^{t}\left(x^{t}, y^{t}\right)}$

This ratio index measures the productivity changes originating from changes in technical efficiency at time period $t$ and time period $t+1$ under the technology in time period $t$. Similarly, technical efficiency changes in time period $\mathrm{t}$ and time period $\mathrm{t}+1$ can also be measured under the technology in time period $t+1$. This Malmquist Index is defined as:

$M_{o c}{ }^{t+1}=\frac{D_{o c}{ }^{t+1}\left(x^{t+1}, y^{t+1}\right)}{D_{o c}{ }^{t+1}\left(x^{t}, y^{t}\right)}$

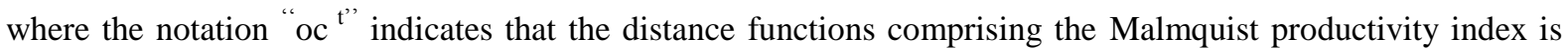
defined on the period $t$ benchmark technology. Defining a Malmquist productivity index on the period $t+1$ benchmark technology would replace "oc t" with " oc ${ }^{\mathrm{t}+1}$ ",

Since both are arbitrary, and since the two indexes are not necessarily equal, it is conventional to define the Malmquist productivity index as the geometric mean of the two as:

$$
\begin{aligned}
M_{o c}\left(x^{t}, y^{t} x^{t+1}, y^{t+1}\right) & =\left\{\left[M_{o c}^{t}\left(x^{t}, y^{t} x^{t+1}, y^{t+1}\right) X M^{t+1}{ }_{o c}\left(x^{t}, y^{t} x^{t+1}, y^{t+1}\right)\right]\right\}^{1 / 2} \\
& =\left[\frac{\left.D_{o c}^{t}{ }^{t+1}, y^{t+1}\right)}{D_{o c}^{t}\left(x^{t}, y^{t}\right)} \times \frac{D^{t+1}{ }_{o c}\left(x^{t+1}, y^{t+1}\right)}{D^{t+1}{ }_{o c}\left(x^{t}, y^{t}\right)}\right]
\end{aligned}
$$

[23]provided an initial decomposition of the index as:

$$
\begin{aligned}
& \mathrm{M}_{\mathrm{oc}}\left(\mathrm{x}^{\mathrm{t}}, \mathrm{y}^{\mathrm{t}}, \mathrm{x}^{\mathrm{t}+1}, \mathrm{y}^{\mathrm{t}+1}\right)=\left[\frac{\left(\mathrm{D}^{\mathrm{t}+1}{ }_{\mathrm{oc}}\left(\mathrm{x}^{\mathrm{t}+1}, \mathrm{y}^{\mathrm{t}+1}\right)\right.}{\mathrm{Dt}_{\mathrm{oc}}\left(\mathrm{x}^{\mathrm{t}}, \mathrm{y}^{\mathrm{t}}\right)}\right] \mathrm{X}\left\{\left[\frac{\mathrm{D}_{\mathrm{oc}}^{\mathrm{t}}\left(\mathrm{x}^{\mathrm{t}+1}, \mathrm{y}^{\mathrm{t}+1}\right)}{\mathrm{D}_{\mathrm{oc}}^{\mathrm{t}+1}\left(\mathrm{x}^{\mathrm{t}+1}, \mathrm{y}^{\mathrm{t}+1}\right)} \mathrm{X} \frac{\mathrm{D}_{\mathrm{oc}}^{\mathrm{t}}\left(\mathrm{x}^{\mathrm{t}}, \mathrm{y}^{\mathrm{t}}\right)}{\mathrm{D}^{\mathrm{t}+1}{ }_{\mathrm{oc}}\left(\mathrm{x}^{\mathrm{t}}, \mathrm{y}^{\mathrm{t}}\right)}\right]\right\} 1 / 2 \\
& =\mathrm{TE} \Delta_{\mathrm{c}}\left(\mathrm{x}^{\mathrm{t}}, \mathrm{y}^{\mathrm{t}}, \mathrm{x}^{\mathrm{t}+1}, \mathrm{y}^{\mathrm{t}+1}\right) \mathrm{X} \mathrm{T} \Delta_{\mathrm{c}}\left(\mathrm{x}^{\mathrm{t}}, \mathrm{y}^{\mathrm{t}}, \mathrm{x}^{\mathrm{t}+1}, \mathrm{y}^{\mathrm{t}+1}\right),
\end{aligned}
$$

Where TE $\Delta \mathrm{c}\left(\mathrm{x}^{\mathrm{t}}, \mathrm{y}^{\mathrm{t}}, \mathrm{x}^{\mathrm{t}+1}, \mathrm{y}^{\mathrm{t}+1}\right)$ measures technical efficiency change which measures the degree of catching up to the best-practice frontier for each observation between time period $t$ and time period $t+1$ and $T \Delta\left(x^{t}, y^{t}, x^{t+1}\right.$, $\mathrm{y}^{\mathrm{t}+1}$ ) measures the geometric mean of the magnitudes of technical change which measures the shift in the frontier of technology ( or innovation ) along rays through $\left(\mathrm{x}^{\mathrm{t}+1}, \mathrm{y}^{\mathrm{t}+1}\right)$ and $\left(\mathrm{x}^{\mathrm{t}}, \mathrm{y}^{\mathrm{t}}\right)$. That is:

TFP growth $=$ technical efficiency change $\mathrm{x}$ technical change

(Catching up effect) (Shift in Frontier effect)

A value of $\mathrm{M}_{\mathrm{oc}}>1$ indicates positive TFP growth from period t to period $\mathrm{t}+1$ while $<1$ shows a TFP growth decline. Note that while the product of the efficiency change and technical change components must by definition equal the Malmquist index, those components may be moving in opposite direction. example a Malmquist index of 1.25 (which signals a productivity gain) could have an efficiency change components less than one (say, 0.5) and a technical change component greater than1(say, 2.5). Both components are measured on the benchmark technologies. Since the best practice technologies may exhibit variable returns to scale, it is desirable to redefine both components on best practice technologies, to see what is left over, and to see if what is left over can be given a meaningful economic interpretation. [23] redefined one component. They decomposed the technical efficiency change component to obtain:

$$
\mathrm{TE} \Delta_{\mathrm{c}}\left(\mathrm{x}^{\mathrm{t}}, \mathrm{y}^{\mathrm{t}}, \mathrm{x}^{\mathrm{t}+1}, \mathrm{y}^{\mathrm{t}+1}\right)=\left[\frac{\mathrm{D}^{\mathrm{t}+1}{ }_{\mathrm{oc}}\left(\mathrm{x}^{\mathrm{t}+1}, \mathrm{y}^{\mathrm{t}+1}\right)}{\mathrm{D}_{\mathrm{o}}^{\mathrm{t}}\left(\mathrm{x}^{\mathrm{t}}, \mathrm{y}^{\mathrm{t}}\right)}\right] \quad X \quad\left\{\frac{\left[\mathrm{D}^{\mathrm{t}+1}{ }_{\mathrm{oc}}\left(\mathrm{x}^{\mathrm{t}+1}, \mathrm{y}^{\mathrm{t}+1}\right) / \mathrm{D}^{\mathrm{t}+1}{ }_{\mathrm{o}}\left(\mathrm{x}^{\mathrm{t}+1}, \mathrm{y}^{\mathrm{t}+1}\right)\right]}{\left[\mathrm{D}_{\mathrm{oc}}^{\mathrm{t}}\left(\mathrm{x}^{\mathrm{t}}, \mathrm{y}^{\mathrm{t}}\right) / \mathrm{D}_{\mathrm{o}}^{\mathrm{t}}\left(\mathrm{x}^{\mathrm{t}}, \mathrm{y}^{\mathrm{t}}\right)\right]}\right\}
$$




$$
\begin{aligned}
& =\operatorname{TE} \Delta\left(\mathrm{x}^{\mathrm{t}}, \mathrm{y}^{\mathrm{t}}, \mathrm{x}^{\mathrm{t}+1}, \mathrm{y}^{\mathrm{t}+1}\right) \quad \mathrm{X} \quad\left[\frac{\mathrm{SE}^{\mathrm{t}+1}\left(\mathrm{x}^{\mathrm{t}+1}, \mathrm{y}^{\mathrm{t}+1}\right)}{\mathrm{SE}^{\mathrm{t}}\left(\mathrm{x}^{\mathrm{t}}, \mathrm{y}^{\mathrm{t}}\right)}\right] \\
& =\mathrm{TE} \Delta\left(\mathrm{x}^{\mathrm{t}}, \mathrm{y}^{\mathrm{t}}, \mathrm{x}^{\mathrm{t}+1}, \mathrm{y}^{\mathrm{t}+1}\right) \times \operatorname{SE} \Delta\left(\mathrm{x}^{\mathrm{t}}, \mathrm{y}^{\mathrm{t}} \mathrm{x}^{\mathrm{t}+1}, \mathrm{y}^{\mathrm{t}+1}\right),
\end{aligned}
$$

where $\operatorname{TE} \Delta\left(\mathrm{x}^{\mathrm{t}}, \mathrm{y}^{\mathrm{t}}, \mathrm{x}^{\mathrm{t}+1}, \mathrm{y}^{\mathrm{t}+1}\right)$ measures pure technical efficiency change on the best practice technologies, measures the change in technical efficiency under the assumption of a VRS and SE $\Delta\left(\mathrm{x}^{\mathrm{t}}, \mathrm{y}^{\mathrm{t}}, \mathrm{x}^{\mathrm{t}+1}, \mathrm{y}^{\mathrm{t}+1}\right)$ measures the change in scale efficiency captures the deviations between the VRS technology and CRS technology at observed inputs from period $t$ to period $t+1$. That means it measures changes in efficiency due to a movement towards or away from the point of optimal scale.

In the second stage analysis to determine factors that affect total factor productivity growth Ordinary Least Square (OLS) model was used. Total factor productivity change scores obtained in the first analysis using the DEA Malmquist Index were used as the dependent variable, while factors such as research and development spending, net value of production, tractors in use, fertilizer price, labor, tractor price and rainfall were used as the independent variables that were thought to affect maize total factor productivity growth in Nigeria. The outcome of this second stage procedure could further serve as guide in designing strategic plan for maize productivity growth in Nigeria. Many previous studies have used this approach in order to determine factors affecting efficiency [26], [27] and [28]. The regression models that could be used in the second stage procedure are the Tobit, Ordinary Least Squares (OLS) and Maximum Likelihood Estimation (MLE). However, [26], [27] and [28] have reviewed these models by using efficiency scores which were generated by either censoring or generated as fractions and have made suggestions under which each one is appropriate to apply. They concluded that Tobit is suitable to use in the second stage when efficiency scores are generated by data censoring process otherwise it is an inconsistent estimator [29] (Greene, 2004). However, when efficiency scores are generated by using DEA where efficiency scores are not censored or corner solution data, but are fractional data the most suitable models are Maximum Likelihood Estimator (MLE) or Ordinary Least Squares (OLS). In this study, based on [26], [27] and [28], Ordinary Least Squares (OLS) was used in the second stage to determine factors affecting total factor productivity growth in Nigeria. To determine the factors affecting total factor productivity growth the Ordinary Least Squares (OLS) model was specified as: $\mathrm{LNY}=\beta_{0}+\beta_{1} \mathrm{LNX}_{1}+\beta_{2} \mathrm{LNX}_{2}+\beta_{3} \mathrm{LNX}_{3}+\beta_{4} \mathrm{LNX}_{4}+\beta_{5} \mathrm{LNX}_{5}+\beta_{6} \mathrm{LNX}_{6}+\beta_{7} \mathrm{LNX}_{7}+\varepsilon$ (6)

Where

$\mathrm{Y}$ stands for the maize total factor productivity scores as the dependent variable, while $\mathrm{X}_{1}$ represents Research and Development Spending in (\$), $X_{2}$ represents Net Value of Production in (\$), $X_{3}$ represents labor(No.) male and female economically active in Agriculture, $X_{4}$ represents fertilizer price $(\$), X_{5}$ represents average annual rainfall $(\mathrm{cm}), X_{6}$ represents number of tractors in use in No. and $X_{7}$ represents tractor price in $\$$ as the independent variables that are thought to affect the maize total factor productivity growth in Nigeria. $\beta_{0}$ represents the intercept term. $\beta_{1^{---}} \beta_{7}$ are unknown parameters to be estimated, $\mathcal{E}$ represents the error term that takes care of unobserved variables, The random variable $\varepsilon_{\mathrm{i}}$ is an independently distributed error term assumed to be normal with zero mean and constant variance, which is denoted by $\varepsilon_{\mathrm{i}} \sim \mathrm{N}\left(0, \delta^{2}\right)$.

\section{Data and Variables}

The main data used in this research study is secondary data. The data were annual for the period from 1971 - 2010. The data consist of quantity of maize output (QP) in tons ; area harvested (AH) in ha; quantity of maize seed (QSD) in tons; quantity of fertilizer (FTQ) in tons; labor (LAB) No. male and female economically active in Agriculture; number of tractors in use (TU) in No.; Net value of production (NVP) in \$; research and development spending (RDS) in \$; fertilizer price (FTP) in \$; tractor price (TP) in \$and average annual rainfall (AAR) in $\mathrm{cm}$. The study relied on data from FAOSTAT, Nigerian Meteorological Agency (NIMEA) and National Bureau of Statistics.

\section{Result of Total Factor Productivity Growth Using DEA Based on Malmquist Index}

Table 1 shows percentage frequency of maize total factor productivity growth in Nigeria. 
Table 1 Percentage Frequency Distribution of Maize Total Factor Productivity Growth in Nigeria from 1971-2010.

\begin{tabular}{lll}
\hline \hline TFP Change & Frequency & $\%$ \\
\hline $0.21-0.300$ & 1 & 2.6 \\
$0.31-0.400$ & 1 & 2.6 \\
$0.41-0.500$ & 0 & 0 \\
$0.51-0.600$ & 3 & 7.7 \\
$0.61-0.700$ & 2 & 5.1 \\
$0.71-0.800$ & 4 & 10.2 \\
$0.81-0.900$ & 3 & 7.7 \\
$0.91-0.990$ & 8 & 20.5 \\
$\geq 1.00$ & 17 & 43.6 \\
\hline Total & 39 & 100 \\
\hline Mean & 1.004 & \\
Progress $43.6 \%$ & & \\
Regress $56.4 \%$ & & \\
\hline
\end{tabular}

Table 1 showed percentage frequency of maize total factor productivity growth in Nigeria from 19712010. The result revealed that for the forty years studied the mean value was 1.004. That affirmed an increase in maize total factor productivity growth of $0.4 \%$. It can be deduced from the Table that, the country had the lowest total factor productivity change scores that ranged from 0.21 to 0.300 and implied $2.6 \%$ of the total observations. The results further show that the country had total factor productivity change scores that lied between $0.71-0.800$ and that represents $10.2 \%$ of the whole observations. Furthermore, the country had total factor productivity change scores that ranged from 0.91-0.99 and that accounted for $20.5 \%$ of the total observations. The country recorded total factor productivity change scores of one and above at $43.6 \%$ of the whole observations. That implied an increase in maize total factor productivity growth. While $56.4 \%$ of the time studied the country had a decrease in maize total factor productivity growth. That confirmed for majority of the time studied the country recorded maize productivity regress. This result tallied with what [15] observed in the manufacturing sector in India that, in majority of the years studied, the Malmquist Productivity Index was less than unitary and explaining the level of productivity for the manufacturing sector. Table 2 shows 5 years average of maize total factor productivity growth, technical and efficiency changes in Nigeria from 1971-2010 using DEA Malmquist Index.

Table 2: Average 5 Years of Maize Total Factor Productivity Growth, Technical and Efficiency Changes in Nigeria from 1971-2010 Using DEA malmquist Index

\begin{tabular}{|c|c|c|c|c|c|c|c|}
\hline Year & Effch & Techch & $\begin{array}{l}\text { \%techch } \\
\text { regress/progress }\end{array}$ & Pech & Sech & $\overline{~ T f f p c h}$ & 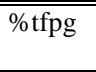 \\
\hline 1971-1975 & 1.000 & 0.965 & -3.500 & 1.000 & 1.000 & 0.965 & -3.500 \\
\hline $1976-1980$ & 1.000 & 0.831 & -16.900 & 1.000 & 1.000 & 0.831 & -16.900 \\
\hline 1981-1985 & 1.000 & 0.972 & -2.800 & 1.000 & 1.000 & 0.972 & -2.800 \\
\hline 1986-1990 & 1.000 & 1.037 & 3.700 & 1.000 & 1.000 & 1.037 & 3.700 \\
\hline 1991-1995 & 1.000 & 1.357 & 35.700 & 1.000 & 1.000 & 1.357 & 35.700 \\
\hline $1996-2000$ & 1.000 & 0.853 & -14.700 & 1.000 & 1.000 & 0.853 & -14.700 \\
\hline 2001-2005 & 1.000 & 0.944 & -5.600 & 1.000 & 1.000 & 0.944 & -5.600 \\
\hline 2006-2010 & 1.000 & 1.334 & 33.400 & 1.000 & 1.000 & 1.334 & 33.400 \\
\hline
\end{tabular}

Table 2 shows that from 1971-1975 on average efficiency change was 1.000 and technological change was 0.965 . This indicated that efficiency change had positively impacted on total factor productivity growth during the period, while technological change had shown a technical regress of 0.965 , which contributed to the decrease in total factor productivity growth by $-3.5 \%$ during the period. Scale efficiency and pure technical efficiency advance positively. [30]in Iran observed TFPG of maize decreased in Fars and Khozestan during 1998-2002. The result also tallied with the finding of [13] on Average he found corn TFP growth negative $(4.5 \%)$ in Iran.

During 1976-1980 on average, the result revealed that, the country had witnessed a maize productivity decrease by $16.9 \%$. This was shown by the contributions from efficiency change of 1.000 and technological change of 0.831 at the time. The source of decrease to total factor productivity growth was due to technological regress from the technological change. From 1981-1985 as indicated by Table 2 on average the country experienced maize total factor productivity decrease in growth by $2.8 \%$. During this period efficiency change had positive impact on total factor productivity growth. What caused the decline was the technical regress during the period. [31] observed a technical regress from 1978-2001.

It can be deduced from Table 2, that from 1986-1990 the country had on average experienced a tremendous increase in maize productivity growth of 3.7\%.It was found that the technical efficiency change components, scale efficiency and pure technical efficiency advanced. Efficiency change and technological 
change scores were1.000 and 1.037, respectively. This has shown the commitment of government towards agricultural sector with a view to increasing maize productivity in the country. The structural adjustment program (SAP) which was introduced in Nigeria in 1986 had led to increases in food, and increase in rural incomes and a dramatic reduction in rural poverty with the incidence decreasing from 51 percent in 1985 to 46 percent in 1992 [32]. So this increase in maize productivity growth during this period (1986-1990) has tallied with what other people have observed in terms of increases in food, rural income and reduction of rural poverty.

Table 2 shows that, from 1991-1995 the country had on average experienced a $35.7 \%$ maize productivity growth. This has shown the highest maize productivity growth ever experienced in the country within the period of study. This has further shown the continuous commitment of government under the SAP period. This immense growth in maize production during this period has justified government programs and policies geared towards increase in agricultural productivity to ensuring self-sufficiency in food production for the teaming population of the country. It was also observed by [33] between 1981 and 1995; TFP grew on a per annum basis by $2.0 \%$. [12] observed impact of SAP on positive growth of maize between 1986 to 1994 in Nigeria.

It can also be observed from Table 2 that from 1996-2000 efficiency change on average 1.000 and technological change was 0.853 . This reveals that the efficiency change has positively contributed to the total factor productivity growth while technological change has negatively contributed to the total factor productivity growth. During this period (1966-2000) the country witnessed productivity decrease as a result of technological regress of $14.7 \%$. The result revealed that this is one of the periods the country had witnessed a huge decrease in maize productivity growth. This could be because during this period not much emphasis on programs that could derive increases in maize productivity growth in the country. Furthermore Table 2 reveals that from 2001-2005 on average the country has witnessed a maize productivity decrease of 5.6\%. This was due to technical regress (0.944)experienced by the country during the period. Compared with the decrease in this period with a decrease (14.7\%) in 1996-2000 relatively the decrease was more intense in 1996-2000.This has shown a response to Nigeria's draft interim poverty reduction strategy in 2001 that anchors on the Nigerian rural development with an overarching goal of bringing about poverty reduction and enhancing food security through suitable agriculture and rural development.

As illustrated in Table 2 the analysis revealed that from 2006-2010 on average the country had efficiency change of 1.000 and technological change of 1.334.This reveals that both efficiency change and technological change contributed positively to maize total factor productivity growth. Technical efficiency components, both scale efficiency and pure technical efficiency advanced positively. During this period the country had experienced an increase in growth by $33.4 \%$. Agricultural programs especially the 7-point agenda implemented by the government during this period had impacted positively on maize productivity growth. The main agricultural goals under the 7-point agenda include food security, access to credit, land reform, agricultural extension, research and training, appropriate technologies etc. geared towards increases in agricultural productivity. Farmers have positively responded to these initiatives and they have impacted positively on maize growth in the country during this period (2006-2010).[34] observed a significant (39\%) productivity growth of maize. [33] also observed between 1981 and 1995, corn TFP grew on a per annum basis by $2.0 \%$. It was also observed by [11] on Corn TFP growth from 1995 to 2002, average annual growth rate of $0.1 \%$, from 2002 to 2005 , with an average annual growth rate of $1.66 \%$.

\section{Factors that Affecting Maize Total Factor Productivity Growth}

It was important to check some properties of the variables that were to be used to determine factors affecting total factor productivity growth. The first was to check whether the variables are stationary or not. A variable is said to be stationary if its mean and variance are constant over time. And this depends on the covariance between the two periods and not the period at which the covariance is computed. When there is no co-integration of the variables to the same order, it will result to regression analysis that is spurious and of no practical use. In order to avoid this problem unit root test was conducted before estimating the model. Unit root test could help to ascertain long run relationship between two or more variables. In order to test the variables for the stationarity, Augmented Dickey Fuller test was conducted. The criteria are that if the absolute value of the test statistics of the Augmented Dickey-Fuller test is higher than the critical absolute value, the null hypothesis is rejected. That implied the variables are stationary. While if the absolute value of the test statistic is less than the critical absolute value, then the null hypothesis is failed to reject. 
Table 3: Augmented Dickey Fuller (ADF) Unit Root Test Results

\begin{tabular}{lllll}
\hline \hline & Level & & $1^{\text {st }}$ difference & Test critical value \\
\hline Variable & Test statistic & Test critical value & Test statistic & -3.610453 \\
RDS & $-3.634479 * * *$ & -3.605593 & $-4.560836^{* * *}$ & -3.610453 \\
NVP & -0.746390 & -2.606857 & $-6.725377 * * *$ & -3.639407 \\
TU & -0.165859 & -2.611531 & $-6.074618^{* * *}$ & -3.610453 \\
FTP & $-3.549055^{* *}$ & -2.936942 & $-8.581218^{* * *}$ & -3.610453 \\
AAR & -0.852047 & -2.606857 & $-7.784163 * * *$ & -3.621023 \\
TP & $-4.429108^{* * *}$ & -3.610453 & $-8.280755^{* * *}$ & -3.615588 \\
LAB & -0.933801 & -3.610453 & $-4.867627 * * *$ & \\
\hline
\end{tabular}

It can be deduced from Table 3 that, some variables were stationary at level while others were not. Then to make the variables stationary first difference of all the variables were taken and found that all the variables were stationary, and co-integrated using Johannes co-integration test at 1 to 1 interval in first difference, which is shown in Table 4.

Table 4: Johannes Co-integration test at 1 to 1 lags Interval (in First Differences): 1 to 1 Test VAR Unrestricted Co-integration Rank Test (Trace).

\begin{tabular}{|c|c|c|c|c|}
\hline Hypothesized & & Trace & 0.05 & \\
\hline No. of CE(s) & Eigenvalue & Statistic & Critical Value & Prob.** \\
\hline None * & 0.935905 & 289.9149 & 159.5297 & 0.0000 \\
\hline At most $1 *$ & 0.707480 & 191.0089 & 125.6154 & 0.0000 \\
\hline At most $2 *$ & 0.682077 & 146.7568 & 95.75366 & 0.0000 \\
\hline At most $3 *$ & 0.623682 & 105.5028 & 69.81889 & 0.0000 \\
\hline At most $4 *$ & 0.473397 & 70.31925 & 47.85613 & 0.0001 \\
\hline At most $5 *$ & 0.438743 & 47.23215 & 29.79707 & 0.0002 \\
\hline At most $6 *$ & 0.348802 & 26.43937 & 15.49471 & 0.0008 \\
\hline At most $7 *$ & 0.263235 & 10.99749 & 3.841466 & 0.0009 \\
\hline
\end{tabular}

In Table 4shows that, the variables are all co-integrated at less than $0.05 \%$ level, hence null hypothesis of no cointegration of the variables is rejected.

Table 5: Determinants of Maize Total Factor Productivity Growth (TFPG) in Nigeria from 1971 - 2010 Using an OLS Regression.

\begin{tabular}{|c|c|c|c|c|}
\hline Variable & Coefficient & Std. Error & t-Statistic & Prob. \\
\hline Constant & -15.51782 & 6.257951 & $-2.479697 * *$ & 0.0186 \\
\hline Research \& Dev. & & & & \\
\hline Spending (LNRDS) & 0.613830 & 0.223666 & $2.744405 * * *$ & 0.0099 \\
\hline $\begin{array}{l}\text { Net value of production } \\
\text { (LNNVP) }\end{array}$ & 0.428896 & 0.216857 & $1.977780 *$ & 0.0566 \\
\hline $\begin{array}{l}\text { Use of tractors (LNUT) } \\
\text { Labor }\end{array}$ & -0.664305 & 0.496683 & -1.337484 & 0.1905 \\
\hline (LNLB) & 0.715483 & 0.388419 & $1.842038 *$ & 0.0748 \\
\hline Fertilizer price (LNFTP) & -0.381160 & 0.095797 & $-3.978811 * * *$ & 0.0004 \\
\hline $\begin{array}{l}\text { Tractor price } \\
\text { (LNTP) }\end{array}$ & -0.035447 & 0.086541 & -0.40959 & 0.6848 \\
\hline $\begin{array}{l}\text { Average annual rain fall } \\
\text { (LNAAR) } \\
\mathrm{R}^{2} 0.4096\end{array}$ & 0.006674 & 0.161013 & 0.041450 & 0.9672 \\
\hline F-statistic 3.1714 & & & & \\
\hline
\end{tabular}

*** Significant at $1 \%$ level

** Significant at $5 \%$ level

*Significant at $10 \%$ level

Table 5 shows factors influencing maize total factor productivity growth which are obtained from OLS estimation. The $\mathrm{R}^{2}$ is 0.41 and F-statistic is 3.17. research and development spending and fertilizer prices are significant at $1 \%$ significant level, while net value of production and labor are significant at $10 \%$ level. All signs of the estimated parameters are in accordance with expected priori.[35] made similar observation that, financial development appear to be one of the most important determinants of TFPG. Another observation was made by[17] on determinants of productivity among manufacturing firms in South-Eastern Nigeria, that Coefficient of net productive assets and labor showed positive and significant effect on output of the firms. 


\section{Conclusion}

Even though the country experienced maize productivity growth in some periods, in majority of the time studied the country experienced technical regress which had led to overall maize productivity decrease. Where such a scenario happened, the growth was driven by inputs growth rather than an output growth. Inputs driven growth is not encouraging because inputs are subjected to diminishing return or they might be scarce, while an output growth is due to an improvement in total factor productivity that is more preferred. The analysis revealed that expanding research and development, net value of production and labor has a significant impact on fostering maize total factor productivity growth in the country. In contrast, increasing fertilize price could lead to a decrease in maize total factor productivity growth in the country. The findings suggest that there is a need to encourage farmers to use new technologies or improved ones, as this will help shift farmers production frontier, thus, help to raise maize productivity growth to a greater level. It is also recommended that, expanding scope of research and development, net value of production and labor could help to raise maize productivity growth in the country. Prices of production inputs like fertilizer should be part of policy priorities because of its inverse impact on maize productivity growth in the country.

[1] IITA, 2012. Maize crop 2012. Downloaded from website: http://www.iita.org/maize

[2] NBS, the Review of the Nigerian Economy 2010 Edition.

[3] USDA, Nigeria Grain and Feed Annual Report 2012. Downloaded from Website: http://www.thebioenergysite.com/report

[4] FARA, Pattern of Change in Maize Production in Africa: Implication for Maize Policy Development. Networking Support Function 3 Regional Policies and Markets 2009

[5] A.A.I. Abdulrahaman and O.M. Kolawole, Traditional Preparations and Uses of Maize in Nigeria Ethnobotanical Leaflets 10: 219227. 2006. C:IUserslcadonilDocuments\MAFAPIMAIZE NIGERIAlLiteraturelTRADITIONAL PREPARATIONS AND USES OF MAIZE IN NIGERIA.mht

[6] USDA, Foreign Agricultural Service: Global Agriculture Information Network, Nigeria Grain and Feed Annual Report, 2010

[7] B. Abdulkarim, D.A. Ibrahim, O. Omotoso, A.G. Shehu, and I. Ukin, Survey of selected agricultural raw material in Nigeria on maize Raw Materials Research \& Development Council, Federal Ministry of Science \& Technology Garki Abuja, Nigeria 2004

[8] WTO, Trade Policy Review, Nigeria, 2011

[9] M.J. Farrell, The measurement of productive efficiency. Journal of the Royal Statistical society, 120(3,) 1957,253-290

[10] S. Malmquist, Index numbers and indifference curves. Trabajos de Estatistica, 4(1), 1953, $209-242$.

[11] Andy, Studies on maize total factor productivity in Liaoning and Jilin province 2012. Downloaded from website:http://www.economics-papers.com

[12] O. Oyakhilomen,U.O. Omadachi, and R.G. Zibah, Assessment of the growth of maize production in the Pre-SAP, SAP and PostSAP Periods in Nigeria: Lesson for sustainable rural economy. Journal of Sustainable Development in Africa. 4( 5), 2012, 18-24

[13] H. Rafiee, M. Zangenehand G.H. Peykani Total factor productivity of corn production in Iran. Scientific Information Data based (SID) 2012

[14] C.E. Onyenweaku, I.N. Nwachuku, and T.C. Opara, Productivity growth in food cropproduction in Imo State, Nigeria. African Crop Science Journal, 18(.3),2010, 89-95

[15] Sh. Sehgaland S.K. Sharma, Total factor productivity of manufacturing sector in India: A regional analysis for the State of Haryana. Int. J. Manag. Bus. Res., 1(.4), 2011, 241-256

[16] C.M. Essa, S. Franklin, and O. Gidon, Factor productivity in smallholder pigeonpea production systems: Empirical evidence from northern Tanzania. Journal of Agricultural Economics and Development 1.( 6), 2012, 138-144.

[17] P.O.O. Nto, P. O. O. \&J.A. Mbanasor, Productivity in agribusiness farms and its determinants in Abia State Nigeria. Journal of Economics and International Finance,.3 (.1), 2012, 662-668

[18] A. Charnes,W. Cooper, and E. Rhodes, Measuring the efficiency of decision making units. European Journal Operational Research. 2(.6), 1978, 429-444.

[19] T.J. Coelli,D.S.P. Rao, andG.E. Bateese, G. E.An introduction to efficiency and productivity analysis Kluwer Academic Publishers, Boston, USA 1998

[20] T.J. Coelli, T. J. and D.S.P. Rao, Total factor productivity growth in Agriculture: A Malmquist index analysis of 93 Countries, 1980-2000Agricultural Economics 32, 2005, 115-134.

[21] R.D. Banker, A. Charnes, and W.W. Cooper, Some models for estimating technical and scale inefficiencies in data envelopment analysis. Management Science, 30(9), 1984, 1078-1092.

[22] D. Caves,L. Christensen, and W. Diewert, The economic theory of index numbers and measurement of input, output and productivity Econometrica 50,1982, 1393-1414

[23] R. Fare, S. Grosskopf,M. Norrisand Z. Zhang, Productivity growth, technical progress and efficiency change in industrialized Countries. American Economic Review 84, 1994, 66-83.

[24] R.W. Shepherd, Theory of cost and production function, Princeton University Press Princeton, NJ. 1970

[25] C.E. Ludena, T.W. Hertel, P.V. Preckel, K. Foster, and A. Nin, Productivity growth and convergence in crop, ruminant, and nonruminant production: measurement and forecasts Agricultural Economics 37, 2007, 1-17.

[26] J. McDonal, Using least squares and Tobit in second stage DEA efficiency analysis. European Journal of Operational Research 197, 2008, 792-798.

[27] A. Hoff, Second stage DEA: comparison of approaches for modeling the DEA scores. European Journal of Operational Research $181,2006,425-435$

[28] R.D. Banker,R. Natarajan, Evaluating contextual variables affecting productivity using data envelopment analysis. Journal of Operations Research 56,2008, 48-58.

[29] W.H. Greene, Econometric analysis fifth edition, Prentice Hall, Upper Saddle River, New Jersey, England 2003

[30] Pajouhesh\&Sazandegi, Investigation of sustainable self-sufficiency in maize production in Iran: total factor productivity approacharticle No. 79, 2009, 169-177

[31] S. N. Rajesh Raj,K. Dharwad, and D. Malathy, Economic reforms and total factor productivity growth in the Indian unorganized manufacturing sector: spatial and temporal analysis 2001. Downloaded from website: http://ssrn.com/abstract=1026542 
[32] World Bank, Global economic prospects and the developing Countries. Washington D. C. The International Bank for Reconstruction and Development/ the World Bank 2002

[33] H. Ruifa, H. Jikun, J. Songqing, and R. Scott, Assessing the contribution of China's research system and CG genetic materials to the total factor productivity of maize in China. 2001

[34] M. Kizito, V.N. Patric, A. Henry, and M. Conrad, Productivity and efficiency analysis of maize under conservation agriculture in Zimbabwe. Selected paper prepared for presentation at the International Association of Agricultural Economists (IAAE) Triennial Conference, Foz do Guacu, Brazil, 18-24 August, 2012.

[35] I. Anders, Determinants of total factor productivity: A literature review. Research and statistics branch. Staff working paper 02/2007.United Nations Industrial Development Organization. 